\title{
A cluster of children with facial nerve palsy in a high prevalence area for COVID-19
}

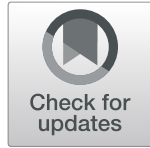

David Barron ${ }^{1}$, Owen Richards ${ }^{*^{*}}$ (D), Fleur Archer ${ }^{1}$, Mohamed Abdelrazek', Rajesh Ranjan² and Omotakin Omolokun ${ }^{2}$

\begin{abstract}
Background: COVID-19 is a disease of varying presentation and neurological sequelae of the disease are being studied. Following a cluster of paediatric facial nerve palsy (FNP) cases in an area of South Wales with a high prevalence of COVID-19, we conducted an opportunistic study to determine whether there has been an increase of incidence of FNP and if there is an association between the FNP and COVID-19 in children.

Methods: We performed a retrospective review of the incidence of FNP between 2015 and 2020 across two hospitals within the health board. The incidence was compared with that in 2020 including a cluster of six children in 14 weeks, presenting to Royal Glamorgan Hospital between June and October.

Results: There were 48 cases of children with FNP across both hospital within the study years. Seven (7) cases in 2020. The incidence was not statistically different in comparison to other years.

Five out of six of these children in 2020 had antibody testing for COVID-19. All serology testing (100\%) returned negative for SARS-CoV- 2 antibodies.

Conclusions: In high prevalence area for COVID-19, cases of children with FNP have not shown a commensurate increase. we have found no causal link between COVID-19 and FNP in children. While this is a small study, larger cohort studies are needed to support this finding.

As new strains of COVID-19 are being reported in UK, South Africa and Brazil, physicians need to continue to be vigilant for consistent pattern of signs and symptoms, especially in children.
\end{abstract}

\section{Background}

To date, COVID-19 infections have passed 84 million cases, with over 1.8 million deaths reported worldwide [1]. While most patients experience mild symptoms or are asymptomatic [2], there is emerging research of differing sequelae of the viral illness. Neurological syndromes that have been associated with COVID-19 [3] include anosmia, ageusia, Guillain Barré syndrome, encephalopathy [4], facial nerve palsies (FNPs) $[5,6]$ and "long COVID" [7]:

As a group of medical students placed in the Paediatric Assessment Unit in the Royal Glamorgan Hospital (RGH), Wales, with the highest prevalence of COVID-19

\footnotetext{
* Correspondence: RichardsO3@cardiff.ac.uk

'School of Medicine, Cardiff University, Cardiff CF14 4XW, UK

Full list of author information is available at the end of the article
}

in South Wales at the time (including remarkably high rates of intra-hospital transmission), we were surprised at the number of children presenting with FNP. According to the paediatric team, this was not a common occurrence. Thus, we reviewed these cases to see if there had been a significant increase in the incidence of FNP in 2020, in comparison to previous years, and whether these cases were related to the COVID-19 pandemic as a neurological sequela of the infection.

\section{Methods}

This was an opportunistic study conducted on the Paediatric ward of the RGH in Wales. It took place between June and October 2020, wherein we collected data from six children with FNP. Each patient was diagnosed, treated and followed up using the same systematic structure, at

C C The Author(s). 2021 Open Access This article is licensed under a Creative Commons Attribution 4.0 International License, which permits use, sharing, adaptation, distribution and reproduction in any medium or format, as long as you give appropriate credit to the original author(s) and the source, provide a link to the Creative Commons licence, and indicate if changes were made. The images or other third party material in this article are included in the article's Creative Commons licence, unless indicated otherwise in a credit line to the material. If material is not included in the article's Creative Commons licence and your intended use is not permitted by statutory regulation or exceeds the permitted use, you will need to obtain permission directly from the copyright holder. To view a copy of this licence, visit http://creativecommons.org/licenses/by/4.0/ The Creative Commons Public Domain Dedication waiver (http://creativecommons.org/publicdomain/zero/1.0/) applies to the data made available in this article, unless otherwise stated in a credit line to the data. 
different points in time. All attendees were required to complete a COVID-19 health-check questionnaire, prior to assessment on the same day of referral. Children with high scores were offered COVID-19 testing.

A clinical diagnosis of FNP was made in all six children, during a 14-week period. The severity of FNP was documented using the House-Brackmann score. Blood pressure checks and a full blood count were done as part of routine care, before commencement of a weeklong course of steroid treatment, following evidence based guidelines [8].

All patients were followed up at one and 4 weeks to check for resolution of facial weakness, and after gaining consent, antibody testing for COVID-19 was performed on them upon recall.

The incidence of FNP in 2020 was compared to previous years' statistics, using statistical package SPSS26. An electronic search was performed for children aged 0-16 years with a clinical coding discharge diagnosis of 'Facial Palsy', 'Bell's Palsy', and 'Idiopathic facial nerve palsy', between the years 2015 to 2020, across two hospitals in Wales - RGH and Prince Charles Hospital (PCH). Children with traumatic birth injuries causing palsy, and children with a secondary diagnosis, such as cerebral palsy, Chiari malformation and other syndromes were excluded from the study.

\section{Results}

There were 48 cases of FNP across both hospitals from the year 2015 to 2020: 30 in RGH and 18 in PCH. The demographics of the patients can be seen in Table 1. Of the six cases in RGH, between June and October 2020, a chi-squared test demonstrated that the change in the incidence of FNP across the years is non-significant ( $p$ value $=0.263$ ).

In the year 2020, two of the six children underwent COVID-19 testing during the episode of FNP, with negative results. One of the six children tested positive 3 months after the initial presentation with FNP and is unlikely to be related.

Five out of six children underwent antibody testing for COVID-19, performed at least 2 weeks after initial presentation with FNP. All serology testing (100\%) returned negative for SARS-CoV-2 antibodies.

\section{Discussion}

This retrospective cohort study conducted across two hospitals found no causal relationship between COVID19 and FNP in the paediatric population. The incidence of FNP in 2020 was not significantly different to the previous 5 years. Of the patients admitted in 2020 with confirmed FNP, no evidence of COVID-19 infection was detected on admission, nor retrospectively via a SARSCoV-2 antibody screen.

While COVID-19 is a disease of highly variable presentation, ranging from asymptomatic infection to multisystem organ failure [9], peripheral neurological disturbance is widely observed in adult patients with anosmia and hypogeusia recognised as common symptoms $[10,11]$.

Table 1 Demographics of Children with Facial Nerve Palsy. Patients Across Two Hospitals in Cwm Taf Morgannwg University Health Board

\begin{tabular}{|c|c|c|c|c|c|c|c|c|c|c|c|c|}
\hline \multicolumn{13}{|c|}{ INCIDENCE OF FACIAL NERVE PALSY } \\
\hline \multicolumn{7}{|c|}{ Royal Glamorgan Hospital - RGH } & \multicolumn{6}{|c|}{ Prince Charles Hospital - PCH } \\
\hline YEAR & 2015 & 2016 & 2017 & 2018 & 2019 & 2020 & 2015 & 2016 & 2017 & 2018 & 2019 & 2020 \\
\hline TOTAL & 4 & 4 & 6 & 5 & 4 & 7 & 3 & 3 & 2 & 5 & 3 & 2 \\
\hline \multicolumn{13}{|l|}{ Age: } \\
\hline $0-5$ & 0 & 0 & 0 & 1 & 2 & 2 & 0 & 1 & 1 & 1 & 0 & 0 \\
\hline $6-10$ & 1 & 1 & 3 & 2 & 1 & 3 & 1 & 2 & 1 & 2 & 2 & 2 \\
\hline $11-15$ & 2 & 3 & 2 & 1 & 1 & 2 & 1 & 0 & 0 & 1 & 1 & 0 \\
\hline $16-20$ & 1 & 0 & 1 & 1 & 0 & 0 & 1 & 0 & 0 & 1 & 0 & 0 \\
\hline \multicolumn{13}{|l|}{ Sex: } \\
\hline Male & 2 & 2 & 3 & 2 & 3 & 3 & 1 & 3 & 1 & 4 & 2 & 1 \\
\hline Female & 2 & 2 & 3 & 3 & 1 & 4 & 2 & 0 & 1 & 1 & 1 & 1 \\
\hline
\end{tabular}


Polyneuropathies, including Guillain-Barré, polyneuritis cranialis and Miller Fisher syndrome, have also been reported as neurological manifestations of COVID-19 in adults [12-14]. Although literature on similar presentations in a paediatric population is scarce, cases of altered taste and smell in the absence of other symptoms have been described in children with confirmed SARS-CoV-2 infection $[15,16]$. Additionally, children who become critically unwell after developing a systemic inflammatory response to COVID-19, known as Paediatric Multisystem Inflammatory Syndrome (PIMS-TS) - temporally associated with SARS-CoV-2 - exhibited global proximal muscle weakness and reduced reflexes [17]. These neurological sequelae, albeit rare, are concerning.

To date, only one case of FNP has been reported in a paediatric patient with COVID-19 [18]. Although FNP is commonly idiopathic, infections such as Herpes Simplex Virus-1, Varicella Zoster Virus and Lyme disease are established causes of facial paralysis [19]. As the clinical manifestations of infection with SARS$\mathrm{CoV}-2$ are still being elucidated, it is reasonable to surmise its possible involvement with FNP. Indeed, in adults, several case reports have described individual instances of unilateral facial palsy in the onset of COVID-19 [20-22]. In a case series conducted in Brazil, Lima et al. [5] described eight patients with COVID-19 who developed FNP during the illness. Similarly, Zammit et al. [23] showed a significantly elevated incidence of FNP in 2020, as compared to 2019, and proposed the COVID-19 pandemic as a reason for the increase. However, of their 30 patients, only 17 (57\%) were tested for COVID-19 and only two returned a positive result. In all the studies, proving a definitive correlation was hindered due to a small sample size.

Whilst a notable cluster of paediatric patients presenting with unilateral facial nerve paralysis was observed from June to October 2020, this study found no association with the ongoing pandemic. Not only were none of the patients positive for COVID-19 on admission, subsequent testing for SARS-CoV-2 antibodies was also negative. Even though it has been suggested that FNP should be recognised as a presenting sign of COVID-19 in children [18], our data suggests otherwise. Larger scale studies with similar results would most likely rule out an association. Of note is that the 27 children with positive COVID-19 results at the RGH did not show any neurologic symptoms (unpublished data).

The limitation of this study was a small sample size, and some antibody tests were performed within the recommended six-week waiting period, potentially allowing insufficient time for detectable immunoglobulin G SARS-CoV-2 antibodies to be produced.

\section{Conclusion}

Our study has not been able to show any causal link between isolated FNP and COVID-19; however, our results should be interpreted with caution as they provide a reassuring insight into the neurological manifestations of COVID-19 in a paediatric population and suggests that FNP in children has no association with this unpredictable disease. We are reassured by overwhelming evidence that only very rarely do children show severe symptoms of COVID-19, such as seen with PIMS-TS. However, as new variants are reported in the UK with increased transmissibility, clinicians need to continue to be vigilant for clinical patterns of this emerging disease, especially in the paediatric population.

\section{Abbreviations \\ SARS-CoV-2: Severe acute respiratory syndrome coronavirus 2; PIMS- \\ TS: Paediatric multisystemic inflammatory syndrome temporally associated with SARS-CoV-2; FNP: Facial Nerve palsy; RGH: Royal Glamorgan Hospital}

\section{Acknowledgements}

We like to acknowledge the kindness and support of the entire paediatric staff of the Royal Glamorgan hospital during the study.

\section{Authors' contributions}

DB contributed to the conception and study design. RR contributed to the acquisition of the data and initial draft of the study. FA contributed to the methodology, initial draft, and revisions of the draft. MA contributed to the analysis and interpretations of the data. OR contributed to the initial draft, analysis, and substantive revisions of the draft. OO contributed to the formatting, editing, revision and supervision of the study. All authors have read and approved the final version of the manuscript.

Funding

No funding was obtained for the study.

\section{Availability of data and materials}

The datasets generated and/or analysed during the current study are not publicly available due [to protection of personal data and fairness.] but are available from the corresponding author on reasonable request.

\section{Declarations}

\section{Ethics approval and consent to participate}

Project received ethical approval and consent to participate, by the Ethics Committee of Cwm Taf University Health board Research and Development department responsible for Prince Charles hospital and Royal Glamorgan hospital.

\section{Consent for publication}

Verbal and written informed consent to participate was obtained from parents of all participants in the study.

\section{Competing interests}

There is no conflict of interest.

\section{Author details}

${ }^{1}$ School of Medicine, Cardiff University, Cardiff CF14 4XW, UK. ${ }^{2}$ Cwm Taf Morgannwg University Health Board, Paediatrics department, Royal Glamorgan Hospital, Ynysmaerdy, UK.

Received: 21 January 2021 Accepted: 5 August 2021

Published online: 25 October 2021

\section{References}

1. Covid19.who.int. 2021. WHO Coronavirus Disease (COVID-19) Dashboard. [online] Available at: <https://covid19.who.int> [Accessed 4 January 2021]. 
2. Tabata S, Imai K, Kawano S, Ikeda M, Kodama T, Miyoshi K, et al. Clinical characteristics of COVID-19 in 104 people with SARS-CoV-2 infection on the diamond princess cruise ship: a retrospective analysis. Lancet Infect Dis. 2020;20(9):1043-50. https://doi.org/10.1016/\$1473-3099(20)30482-5.

3. Ellul MA, Benjamin L, Singh B, Lant S, Michael BD, Easton A, et al. 'Neurological associations of COVID-19', (pp. 1474-4465, electronic); 2020.

4. Paterson RW, Brown RL, Benjamin L, Nortley R, Wiethoff S, Bharucha T, et al. The emerging spectrum of COVID-19 neurology: clinical, radiological and laboratory findings', (pp. 1460-2156, electronic); 2020

5. Lima MA, Silva MTT, Soares CN, Coutinho R, Oliveira HS, Afonso L, et al. Peripheral facial nerve palsy associated with COVID-19. J Neuro-Oncol. 2020; 26(6):941-4. https://doi.org/10.1007/s13365-020-00912-6.

6. Codeluppi L, Venturelli F, Rossi J, Fasano A, Toschi G, Pacillo F, et al. 'Facial palsy during the COVID-19 pandemic', (pp. 2162-3279, Electronic); 2020.

7. The Lancet. Facing up to long COVID. Lancet. 2020:396(10266):1861.

8. Baugh RF, Basura GJ, Ishii LE, Schwartz SR, Drumheller CM, Burkholder R, et al. Clinical practice guideline: Bell's palsy. Otolaryngol Head Neck Surg. 2013;149(3 Suppl):S1-S27. https://doi.org/10.1177/0194599813505967.

9. Chen N, Zhou M, Dong X, Qu J, Gong F, Han Y, et al. Epidemiological and clinical characteristics of 99 cases of 2019 novel coronavirus pneumonia in Wuhan, China: a descriptive study. Lancet. 2020;395(10223):507-13. https:// doi.org/10.1016/S0140-6736(20)30211-7.

10. Wu Y, Xu X, Chen Z, Duan J, Hashimoto K, Yang L, et al. Nervous system involvement after infection with COVID-19 and other coronaviruses. Brain Behav Immun. 2020;87:18-22. https://doi.org/10.1016/j.bbi.2020.03.031.

11. Mao L, Jin H, Wang M, Hu Y, Chen S, He Q, et al. Neurologic manifestations of hospitalized patients with coronavirus disease 2019 in Wuhan, China. JAMA Neurol. 2020;77(6):683.

12. Toscano G, Palmerini F, Ravaglia S, Ruiz L, Invernizzi P, Cuzzoni M, et al. Guillain-Barré 'syndrome associated with SARS-CoV-2'. N Engl J Med. 2020; 382(26):2574-6. https://doi.org/10.1056/NEJMc2009191.

13. Gutiérrez-Ortiz C, Méndez-Guerrero A, Rodrigo-Rey S, San Pedro-Murillo E, Bermejo-Guerrero L, Gordo-Mañas R, et al. Miller fisher syndrome and polyneuritis cranialis in COVID-19. Neurology. 2020;95(5):e601-5. https://doi. org/10.1212/WNL.00000000000009619.

14. Kopscik M, Giourgas B, Presley B. A case report of acute motor and sensory polyneuropathy as the presenting symptom of SARS-CoV-2. Clin Pract Cases Emerg Med. 2020;4(3):352-4. https://doi.org/10.5811/cpcem.2020.6.48683.

15. Erdede O, Sarı E, Uygur Külcü N, Uyur Yalçın E, Sezer Yamanel R. An overview of smell and taste problems in paediatric COVID-19 patients. Acta Paediatr. 2020;109(11):2184-6. https://doi.org/10.1111/apa.15515.

16. Mak P, Chung K, Wong J, Shek C, Kwan M. Anosmia and ageusia: not an uncommon presentation of COVID-19 infection in children and adolescents. Pediatr Infect Dis J. 2020;39(8):e199-200. https://doi.org/10.1097/INF. 0000000000002718.

17. Abdel-Mannan O, Eyre M, Löbel U, Bamford A, Eltze C, Hameed B, et al. Neurologic and radiographic findings associated with COVID-19 infection in children'. JAMA Neurol. 2020;77(11):1440.

18. Theophanous C, Santoro J, Itani R. Bell's palsy in a pediatric patient with hyper IgM syndrome and severe acute respiratory syndrome coronavirus 2 (SARS-CoV-2). Brain and Development. 2020;43(2):357-9. https://doi.org/10.1 016/j.braindev.2020.08.017.

19. Owusu J, Stewart C, Boahene K. Facial nerve paralysis. Med Clin N Am. 2018; 102(6):1135-43. https://doi.org/10.1016/.mcna.2018.06.011.

20. Goh Y, Beh D, Makmur A, Somani J, Chan A. Pearls \& oy-sters: facial nerve palsy in COVID-19 infection. Neurology. 2020;95(8):364-7. https://doi.org/1 0.1212 WNL.00000000000098863.

21. Homma Y, Watanabe M, Inoue K, Moritaka T. Coronavirus disease-19 pneumonia with facial nerve palsy and olfactory disturbance. Intern Med. 2020;59(14):1773-5. https://doi.org/10.2169/internalmedicine.5014-20.

22. Katyal N, Narula N, Acharya S, Govindarajan R. Neuromuscular complications with SARS-COV-2 infection: a review. Front Neurol. 2020;11(1052). https:// doi.org/10.3389/fneur.2020.01052.

23. Zammit M, Markey A, Webb C. A rise in facial nerve palsies during the coronavirus disease 2019 pandemic. J Laryngol Otol. 2020;134(10):905-8. https://doi.org/10.1017/S0022215120002121.

\section{Publisher's Note}

Springer Nature remains neutral with regard to jurisdictional claims in published maps and institutional affiliations.

Ready to submit your research? Choose BMC and benefit from:

- fast, convenient online submission

- thorough peer review by experienced researchers in your field

- rapid publication on acceptance

- support for research data, including large and complex data types

- gold Open Access which fosters wider collaboration and increased citations

- maximum visibility for your research: over $100 \mathrm{M}$ website views per year

At $\mathrm{BMC}$, research is always in progress.

Learn more biomedcentral.com/submissions 